\title{
Karst porosity estimations from archive cave surveys - studies in the Buda Thermal Karst System (Hungary)
}

\author{
Gáspár Albert*1, Magdolna Virág ${ }^{2}$, and Anita Erőss ${ }^{2}$ \\ ${ }^{1}$ Eötvös Loránd University, Budapest - Department of Cartography and Geoinformatics \\ ${ }^{2}$ Eötvös Loránd University, Budapest - Department of Physical and Applied Geology
}

\begin{abstract}
The Buda Thermal Karst System is located under the densely populated hills of Budapest. One of its caves (Pál-völgy Cave System) is the longest cave of Hungary with $30.1 \mathrm{~km}$. The research was done in this area as a methodological study to estimate karst porosity parameters of aquifers or hydrocarbon reservoirs. In this study two modeling methods are demonstrated. The volumetric modeling method was primarily aimed to determine the macro-scale $(>0.5 \mathrm{~m})$ conduit porosity (referred as macroporosity) of the study area as percentage of the incorporating limestone and marl. This method is based on archive survey data (maps and records). Through this method, morphometric parameters and the approximate sizes of the unexplored cave parts were also calculated. The porosity modeling was aimed at the estimation of the meso-scale $(0.02-0.5 \mathrm{~m})$ and macro-scale conduit porosity. It is based on rock face measurements near the Pál-völgy Cave System and image analysis. The matching macroporosity estimations of the two methods suggest that the map-based volumetric modeling method can be a useful tool for karstologists and modeling experts to extract as much information as possible from existing cave maps, even if the records of the original survey were lost or scanty. With the matrix porosity data published earlier from this area, and the conduit porosity calculated from the models, hydrological models of the area can be completed.
\end{abstract}

Keywords: $\quad$ cave surveys; karst porosity; 3D models; Buda Thermal Karst System; porosity model

Received 7 February 2014; Revised 27 October 2014; Accepted 19 November 2014

Citation: $\quad$ Albert G., Virág M. and Erőss A., 2015. Karst porosity estimations from archive cave surveys studies in the Buda Thermal Karst System (Hungary). International Journal of Speleology, 44 (2), 151-165. Tampa, FL(USA) ISSN 0392-6672 http://dx.doi.org/10.5038/1827-806X.44.2.5

\section{INTRODUCTION}

Traditionally, the primary purpose of cave maps (surveys) was to characterize and compare caves in terms of their dimensions, shapes and patterns. From cave survey data, maps are compiled to assist the orienteering in the passages; however many authors also have tackled the determination of cave volumes (Jakucs, 1948; Horváth, 1965; Curl, 1986; Palmer, 1995; Klimchouk, 2004; Finnesand \& Curl, 2009). The dataset of a survey consists of the coordinates of series of points (survey stations) measured from the cave entrance, and some additional data regarding the dimensions of the cave passage at the measured points (Jeannin et al., 2007). Usually the data of archive surveys is not suitable for modeling the true geometry of the passages. The construction of a realistic 3D cave model requires an accurate surveying method and a dense point network (e.g., Jakopin, 1981; Kincaid, 2000; Fish, 2001; Jeannin et al., 2007; Pachos, 2008). While the recent survey methods use laser measurement tools which can produce dense data with proper precision (e.g., Heeb, 2008; Pachos, 2008; Gede et al., 2013), the traditional methods measure (or sometimes estimate) only the length, width and height of a passage at each station (e.g., Jeannin et al., 2007). Volumetric 3D models (sketchy approaches of the true geometry aimed to estimate the volume of the surveyed part of the cave) however can be created using these data.

Before the digital era, survey data were used to create scaled plaster mockups of caves (Jakucs, 1948; Horváth, 1965) and stereological methods were also used to approximate the volumes of caves from 2D passage profiles (i.e., Jakopin, 1981). There is also a variety of methods of volumetric modeling using computers. For a long time, computerized cave surveying applications were used to create only line plots of the caves. A line plot shows only the line network of a survey's station-target pairs (survey 
shots). Even today, only few applications are capable to generate volume around the survey shots, and they use different approaches. Some of these applications (e.g., Compass, Visual Topo, and Therion) are widely used among speleologists for creating visually enhanced 3D models of caves from survey data. In Compass, Fish (2001) created tubes around the shots and summed their volumes, while Kincaid (2000) created surface models (3D meshes) for the floor and the ceiling of the cave passages and calculated the volume in between. From these models, the surveyed cave volume can be estimated.

The estimation of the volume can be absolute, giving the total size of the cave in cubic meters, and can be relative, giving the ratio of the void and the surrounding rock body. The latter is usually called porosity. In karst hydrogeology studies (e.g., Király, 1975; Palmer, 1999) a three-component porosity model is used: the matrix, the fracture (fissure) and the cave (solutional) porosity. The matrix porosity consists of tiny intergranular voids (pores) and is commonly the result of sedimentation and diagenesis. The fissures are planar discontinuities such as bedding planes, joints and faults. The fracture (fissure) porosity is the result of late diagenesis, tectonism and weathering. The cave porosity is a result of speleogenesis and can contain conduits (elongated planar or tubular openings) and caverns (Klimchouk \& Ford, 2000; Worthington et al., 2000; Klimchouk, 2006; Filipponi et al., 2009).

The terms "conduit porosity" (e.g., Pardo-Iguzquiza et al., 2011) and "channel porosity" (e.g., Worthington et al., 2000) are also used for the relative volume of the surveyed caves, however the term "conduit" is also used in hydrological contexts for smaller (long but at least $1 \mathrm{~cm}$ wide) openings (Ford \& Williams, 1989). If a conduit is accessible to people, it is considered to be a cave (Worthington, 1999). The cave porosity is known as the relative volume of the "proper cave" if the diameter of the cavity is greater than $0.5 \mathrm{~m}$ (Curl, 1986). In this study these man-sized conduits are named passages, and the relative volume of these passages is called macro-scale conduit porosity (macroporosity). The relative volume of solutionally enlarged fractures, fissures, and small $(<0.5 \mathrm{~m})$ cavities was distinguished from the latter, and is termed meso-scale conduit porosity (mesoporosity).

Estimations of the relative volumes of caves outlined by Worthington (1999) used the minimum rectangular block (edges parallel with the coordinate axes) that can contain the passage system. The channel porosity was defined as the volume of the mapped cave divided by the volume of the rectangular block (Worthington, 1999; Worthington et al., 2000). The same method was used by Pardo-Iguzquiza et al. (2011) to calculate the spatial density of conduits (where conduits are cave segments between two survey stations). Other cave morphometric studies suggest using irregular-shaped polygons to delineate cave fields (e.g., Klimchouk, 2003; 2006; Finnesand \& Curl 2009; Piccini 2011). Klimchouk (2003 and 2006) found that changing the shape of the incorporating rock mass from rectangular to polygonal increased the cave porosity drastically.
In this study two methods were used to estimate the porosity of the surrounding karst. These methods are described as volumetric and porosity modeling. The volumetri-c model was created from the archive surveys of the studied caves, while the porosity model was based on the measurements and photo documentation of the karst phenomena on the walls of an abandoned limestone quarry. Both of the modeling methods aim for the quantitative estimation of the conduit porosity, but on different scale. The volumetric model represents the macro-scale $(>0.5 \mathrm{~m})$ conduit porosity, while the porosity model represents all the discontinuities (caverns, fractures, fissures, solution marks, etc.) of the rock volume on the scale of the naked eye (approximately $>2 \mathrm{~cm}$ which was practically the resolution of the photos). The matrixand the fracture porosity is not included in this model. The porosity model thus represents the meso-, and macro-scale conduit porosity together, but the two categories are distinguishable in the model. There is also qualitative difference between the two methods. The volumetric models were based on mainly secondhand data collected from archive maps, while the porosity model was based directly on the quantitative data of field observations. The results of the two methods can be compared, and the comparison of the two models played a major role in the validation process.

Manda and Gross (2008) used 2D images to calculate the total porosity in a way similar to the image analysis of the quarry walls. In their case, the image was an optical borehole televiewer picture of a small test area (from a $25 \mathrm{~m}$ deep drill-hole). Their results were between $10-48 \%$ for the total porosity (matrix-, fracture- and cave porosity together) with a large variance. Heward et al. (2000) analyzed the borehole core-samples with computer tomography (CT) and calculated the porosity from the analysis of the tomographic images. They studied a deep karst area which had very similar complex genesis as the caves of the Buda Thermal Karst System (BTKS). They measured $0-16.8 \%$ total porosity from several boreholes. Chen et al. (2008) modeled the fracture porosity of a karst reservoir based on the borehole and seismic data, and reported $0-15 \%$.

Other studies in cave (and porosity) modeling step out from the bounds of the known size of a single cave using fractal dimensions and geometries (e.g., Curl, 1986; Laverty, 1987; Verbovšek, 2007). These studies are aimed to estimate porosity volumes not only in the vicinity of a cave, but over the entire karst region. To achieve such aims the summed length of all known caves of the studied karst region must be known. However, the inhomogenious geological settings (e.g., faulted rocks and multi various carbonates) and complex hydrological evolution of certain regions may invalidate these models.

Determination of the volume of cave passages is important not only for cavers, but also for geologists, biologists or health care professionals, because subsurface voids are potentially suitable for containing water, hydrocarbons, or breathable air. The models of this study were created for geological purposes aiming 
directly to make estimations of conduit porosity. According to the studies of exploration wells ( $\mathrm{VH}-1$, L-VII) near the study area (Fig. 1), the average matrix porosity of the limestone and calcarenite is 5-10\%, max. 25\% (Kleb et al., 1993; Juhász et al., 2007). The aim of this study was to complete these results with estimated conduit porosity percentages for the study area.

In hydrogeological studies, the conduit porosity is considered as an important influencing factor of permeability (Worthington, 1999); however, the scale effect (Király, 1975) has to be taken into account as well. Since our models aim to estimate conduit porosity, the results may be used for permeability modeling.

\section{STUDIED CAVES}

The studied caves are located in the underground of Budapest (Fig. 1) and are included in the Buda Thermal Karst System (BTKS), which is part of the UNESCO World Heritage since 1993 (UNESCO, 1993). The system originally consisted of six large caves (longer than $1 \mathrm{~km}$, with vertical extent between 50 and $130 \mathrm{~m}$ ), but a natural connection between two of them (Pál-völgy and Mátyás-hegy caves) was explored recently. These two caves, together with other newlydiscovered (Harcsaszájú- and Hideglyuk caves) and recently connected caves are now called the Pál-völgy Cave System. According to the National Cave Register (Ministry of Rural Development, 2013), the number of known caves within the BTKS in the close vicinity of the study area is 98, and the total length of the

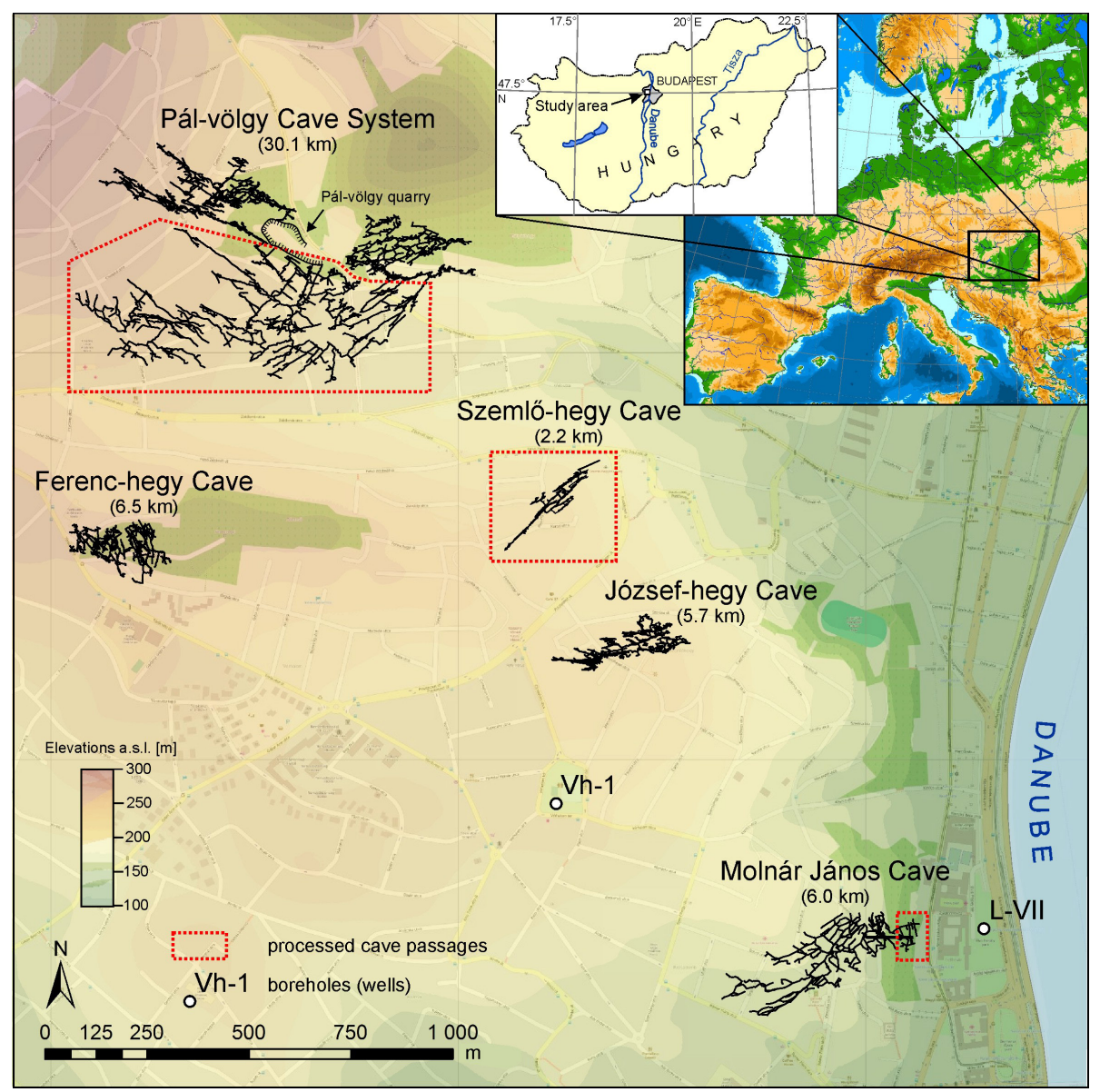

Fig. 1. Map of the study area (Rózsadomb) with the five larger caves. The map is based on the data of the National Cave Register (Ministry of Rural Development, 2013), the OpenStreetMap Project (OSM) and SRTM elevation data. five larger caves is now more than $50 \mathrm{~km}$. All are considered typical hypogenic caves based either on morphological observations (e.g., Dublyansky, 2000; Ford \& Williams, 2007; Klimchouk, 2007; Palmer, 2007), or on recent hydrogeological studies (Erőss et al., 2012).

The three longest caves of the BTKS were subject of volumetric studies:

1) The Molnár János Cave (MJC) is one of the largest known active phreatic hydrothermal caves of the world. The underwater cave, which is connected with the thermal spring of a nearby spa, was explored in 1972. The first map was drawn in 1984 by Kalinovits. In 2002, new submerged passages were discovered, and now the total length is more than $6 \mathrm{~km}$ (Kalinovits, 2006). The volume estimation model presented here is limited to the few hundred meters of a high resolution map from 1984. The MJC is a good example of modern phreatic hypogenic caves, since it has been formed by mixing corrosion below the water table (Erôss et al., 2012). Mixing corrosion occurs where flow systems of different orders (with different chemistry and temperature) meet via tectonic lines or through diffusion.

2) The Szemlö-hegy Cave (SHC) is considered one of the most precisely surveyed caves in the BTKS due to its relative small total length $(2.2 \mathrm{~km})$ and its therapeutic utilization. Original explorations already tried to estimate the volume of the cave, but the estimating method was not documented (Horváth, 1965). Spheroidal niches (e.g., cupolas or bell holes) are quite usual in the SHC, mainly at the top of the passages. The dissolution of these features was modeled by Szunyogh (1989).

3) The Pál-völgy Cave (PVC) is also a well-known cave. Due to the intensive exploration, new passages are revealed almost every week. Another more extended cave system around the Pál-völgy Cave, known originally as individual caves, was recently connected to it, forming the Pál-völgy Cave System (Zentay, 2005; Takács-Bolner, 2011). The total length is $30.1 \mathrm{~km}$ at the moment.

\section{GEOLOGICAL SETTINGS}

The hills of the BTKS (Buda Hills) are built of Mesozoic and Cenozoic sedimentary rocks. By the Eocene, the Jurassic and Cretaceous formations were eroded, and only the Triassic carbonates remained 
(e.g., Poros et al., 2012). On the eroded surface of the Triassic (i.e., Dachstein Limestone, cherty limestone and dolomite and "Hauptdolomit" - Haas 1988; Haas et al., 2000), a Paleogene transgressional sequence (bauxitic clays, limestones, marls, clays and sandstones) has deposited (e.g., Wein, 1977; Kázmér, 1985; Báldi, 1986; Nagymarosy \& Báldi-Beke, 1988; Fodor et al., 1994; Nagymarosy, 2001; Báldi-Beke, 2003). After a long subareal exposure in the Miocene, Late Miocene-Pliocene and Quaternary freshwater limestones formed at the margins of the hills, contemporarily with siliciclastic sediments (Müller \& Magyar, 2008). The hills themselves were covered with loess and clayey slope-debris in the Pleistocene, and travertine has formed nearby the springs (Scheuer \& Schweitzer, 1988; Kele et al., 2009, 2011).

In the study area (Fig. 1 - Rózsadomb) the cave passages of the BTKS developed mainly in Eocene limestone, but the upper parts occasionally extend into Eocene marl, and in two of them (PVC, and József-hegy Cave) the lower parts can reach Triassic carbonates underlying the Eocene succession (Fig. 3). Tectonic control is present (dextral-strike-slip zone) in all the caves of Rózsadomb producing vertically extended (narrow and high) passages. According to detailed geological surveys of the surrounding Buda Hills (Fodor et al., 1992; Benkovics et al., 1999; LeélŐssy et al., 2011; Leél-Őssy \& Surányi, 2003; Szanyi et al., 2012), the speleogenesis was controlled by faults with NE-SW and NW-SE directions (Fig. 1) that were formed during the Late Eocene-Early Miocene and Late Miocene-Pliocene (Fodor et al., 1994). Besides the tectonic control, the network maze of cave passages follows the $25-30^{\circ}$ south-southwestward dip of the Upper Eocene limestone and marl in PVC and MJC. However, in the SHC only the tectonic control is present in the form of NE-SW striking passages (Fig. 2).

During the Miocene, mineral veins (calcite, barite and sulfides) were formed along the faults, and later (mainly in the Pleistocene) they gave place to the cave forming as a different phase in the evolution of one single hydrothermal system (Poros et al., 2012). The BTKS has a hypogenic origin, and mixing corrosion has been the dominant cave forming process (e.g., Leél-Össy \& Surányi, 2003; Erőss et al., 2012). Although it is mainly in unconfined conditions now, influenced by adjoining confined parts of the aquifer (Erőss et al., 2012), it is possible that it was in confined conditions during the early speleogenesis. Based on the analogy of the still active MJC, the cave forming processes were probably most intensive near the discharge locations (paleo-springs) of the aquifer. In these locations, several types of carbonates, including marl, limestone and dolomite, were present at that time. Thus, the host rocks of the speleogenesis were also different in the study area (Fig. 3).

\section{VOLUMETRIC CAVE MODELING BASED ON ARCHIVE MAPS}

The volumetric model is based on the segmentation of the cave passages according to the station-target pairs, and aims to produce 3D models for each cave segment using the width $(w)$ and height $(h)$ of them, and the length, direction and dip data of the survey shots. It is quite similar to Fish's (2001) geometric approach; however, we used statistical parameters to produce an estimate for the reliability of the model. It was necessary because archive cave maps were processed primarily. The volumetric model determines the macro-scale conduit porosity. Virtual models were created in the modeling environment (AutoCAD), where the model can be processed using tools such as merging/ extracting $3 \mathrm{D}$ objects and querying volume data.

\section{Source and error calculation of survey data}

The studied caves were surveyed and documented by speleologists of the Hungarian Speleological Society (HSS). These documents are usually available only on paper, since the process of the cave exploration goes back far in the past and the progress of digital archiving is slow. Speleological documentation includes maps, cave descriptions and records (paper and digital) of measurements.

During the cave exploration, speleologists used traditional cave mapping instruments such as measuring tape, compass and clinometer. Survey stations were usually set every $5-10 \mathrm{~m}$, but the average density of the stations varies in each part of the cave. In the records the measurements (shots) are stored in pairs. Each pair consists of a station and a target point and makes up a spatial vector. The cave length is the sum of the length of these vectors. In the PVC and the MJC the records of this polygonal surveying was available from the archives. In the SHC the original station-target records were not preserved, but most of the original stations were physically marked in the cave and were later used

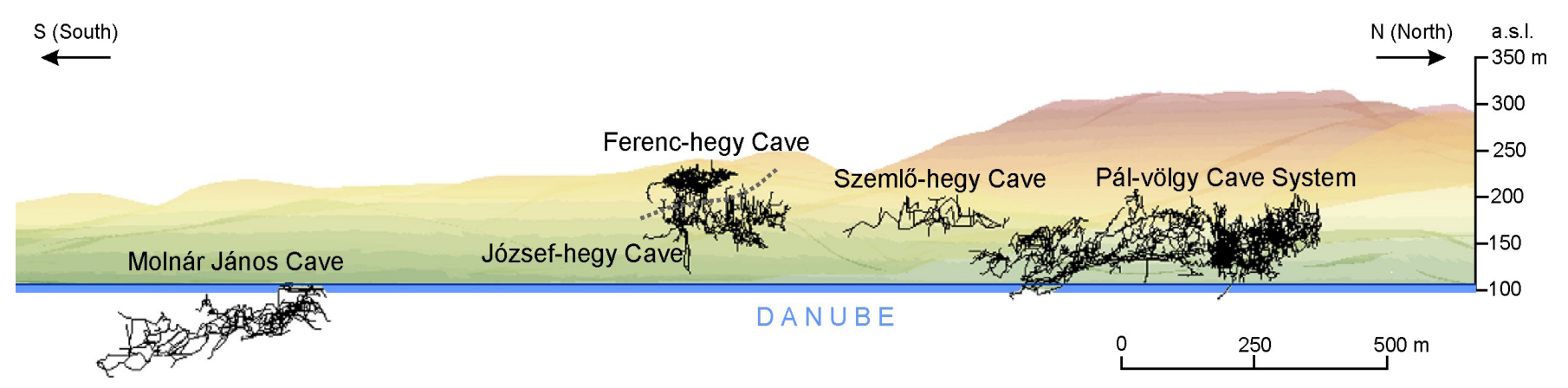

Fig. 2. Location of the larger caves in the BTKS from a horizontal view related to the level of the river Danube. No vertical exaggeration. The southward dip of the enclosing stratigraphic units has a control over the cave forming. 


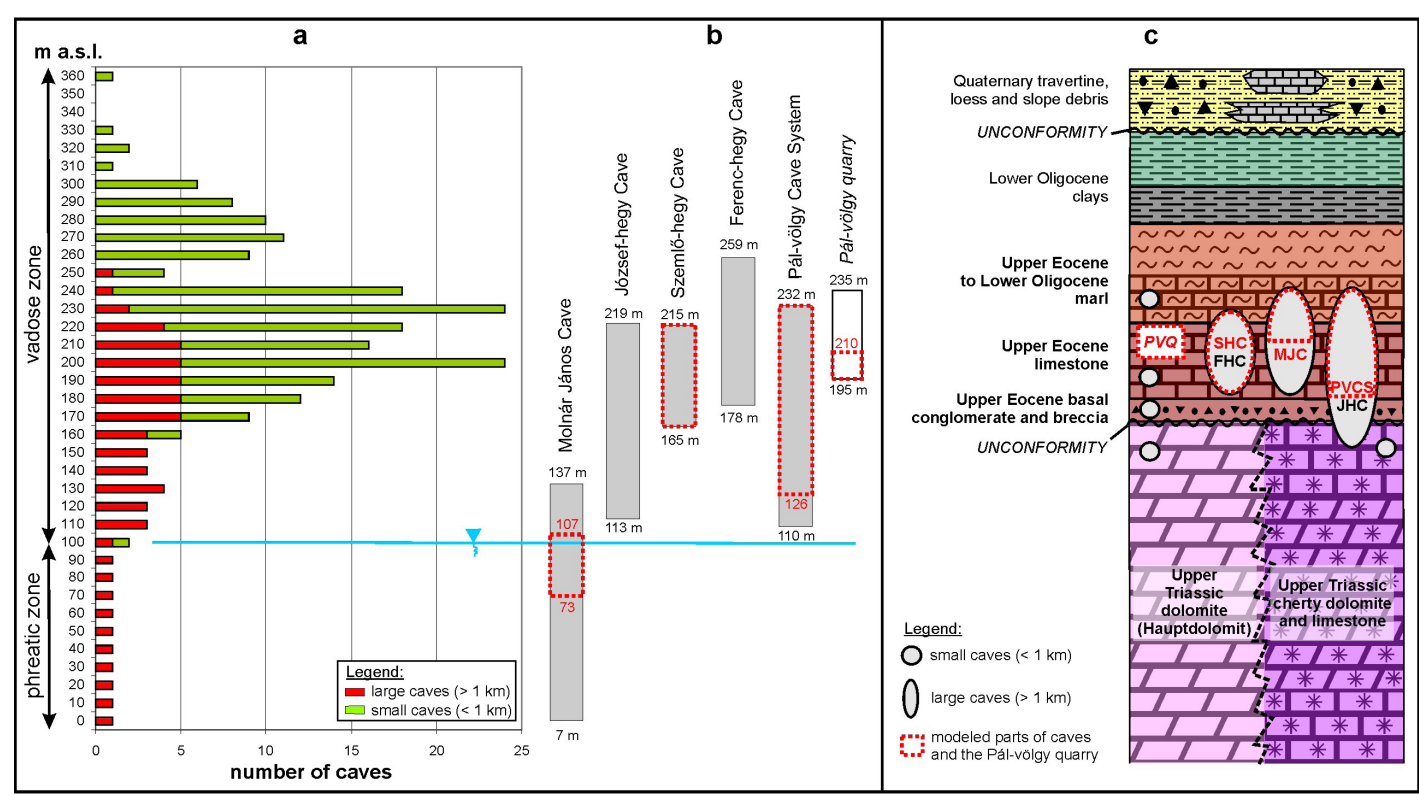

Fig. 3. a) Frequency and elevation distribution of known cave passages in the Rózsadomb area; b) Vertical extent of the large caves and the Pál-völgy Quarry (from/to a.s.I.); c) Schematic lithological column of Rózsadomb (positions of the caves are indicated by circles). PVQ = Pál-völgy Quarry; SHC = Szemlö-hegy Cave; FHC = Ferenc-hegy Cave; MJC = Molnár János Cave; PVCS = Pál-völgy Cave System; JHC = Józsefhegy Cave (a, b: modified after Virág et al., 2013).

as reference points. During modeling these reference points were used in the same way as those which were real station-target pairs. In all cases, the vectors were joined together and they formed a complex 3D network.

The width and height data (horizontal and vertical diameter) of the passage segments between (or at) the stations were seldom available in the records, therefore, these values were obtained from the archive maps, which usually contain mapped transversal profiles of the cave passages (Fig. 4); so the width $(w)$ and the height $(h)$ of these segments were collected from here. If transversal profiles are not shown on the maps, the widths were interpreted with direct measures on the maps at each station-target segment. The obtained values were usually the most representative widths of the segments. The heights of these segments were collected consulting speleologists. The latter method was used only in the PVC.

Since the original data were measured using compass and tape, the coordinates of the stations were generated from the length and orientation (azimuth and dip) data. This means that the confidence of the coordinates is getting worse as the distance increases from the cave portal, because the possible systematic error in the measure process was cumulative. This error can be calculated using closed loops, when cave passages are joining physically, but they do not join according to the measurements (Fish, 2001; Jeannin, et al., 2007). The general error of the closed loops can be calculated for the PVC (16 loops, which are $23 \%$ of the $3 \mathrm{D}$ length) and the MJC (1 loop, which is $30 \%$ of the length), where the original survey data were available. The error varies from 0 to $9.52 \%$ and the median was $1.43 \%$ in the loops.
Construction of the cave model

At each station the width $(w)$ and height (h) were processed to create a virtual profile of the segment. The vertical position of the stations relative to the passage floors was not mentioned neither in the records, nor on the maps. Without this information the reconstruction of the passage volumes around the $3 \mathrm{D}$ vectors is uncertain. From the surveying techniques in the studied caves this position was however estimated and was included in the method. Using a random variable (V) with a certain $(90 \%)$ possibility the probable vertical position of the stations was calculated. A random coefficient ( $($ ) was also introduced to simulate the measurement errors and the uncertainty of the reconstructed positions of the stations. The resulting profile is an irregular quadrangle, of which absolute height and width is equal to $h$ and $w\left(w=\left|x_{L}\right|+x_{R} ; h=\left|y_{D}\right|+y_{U}\right)$. Within this certain frame, the shape of the quadrangle was random because of the $\xi$. These quadrangles were extruded along the individual segment and served as a basic component of the model.

The reliability of this method was checked comparing the area of the mapped profiles and the ones generated in the model for the same segments of the caves. To calculate the reliability, 3-5 distinct profile series were generated, and the correlation results with the measured profiles were averaged and

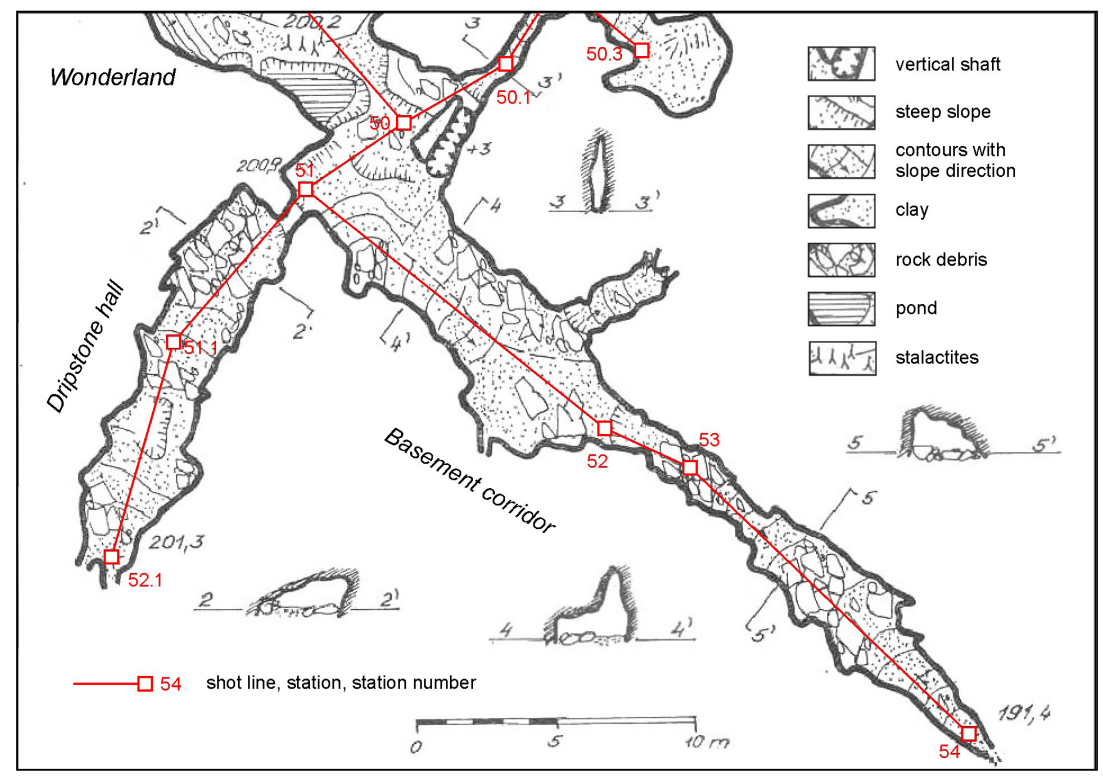

Fig. 4. Part of the published map of the Pál-völgy Cave (modified after Kárpát, 1983), showing four transversal profiles. 
considered as the error of the method. The average error was calculated separately for each cave. The smallest average error occurred in the SHC (8.4\%), while in the PVC it was $13 \%$ and $13.7 \%$ in the MJC (Table 1).

Table 1. The results of the comparison between the modeled and the measured passage profiles in the caves of the BTKS.

\begin{tabular}{|l|c|c|c|}
\cline { 2 - 4 } \multicolumn{1}{c|}{} & PVC & SHC & MJC \\
\hline Error [\%] & 13 & 8.4 & 13.7 \\
\hline Distribution [\%] & 35.4 & 22.8 & 24.8 \\
\hline Correl. coef. & 0.84 & 0.97 & 0.93 \\
\hline No. of mapped profiles & 56 & 66 & 36 \\
\hline
\end{tabular}

The four virtual points (L, R, U, D), which frame the profile, are in a local planar, orthogonal coordinate system $(x, y)$ normal to the direction of the station pairs. The origin $(\mathrm{O})$ of this system is one of the stations, and the extrusion of the virtual profile along the vector originates from here. In those cases where measured profiles were available, the intersecting point of the plane of the measured profile and the vector between the station and target point was projected onto the local coordinate system of the station. Each frame point has an $x$ and a $y$ coordinate in the local coordinate system. Their positions are derived from the width $(w)$ and height $(h)$ data. The four frame points are always at the same position relative to the stations: $\mathrm{L}$ is on the left, $\mathrm{R}$ is on the right side, $\mathrm{U}$ is at the top and $\mathrm{D}$ is at the bottom (Fig. 5).

In the following concatenations the calculation method is given for one single virtual profile. The parameters are based on the surveying practice of the PVC, where the stations are usually positioned in the middle of the passages (Fig. 4). The profiles are mostly extended in height relative to the width, and the passages are typically wider at the bottom in respect to the top. Putting these characteristics into

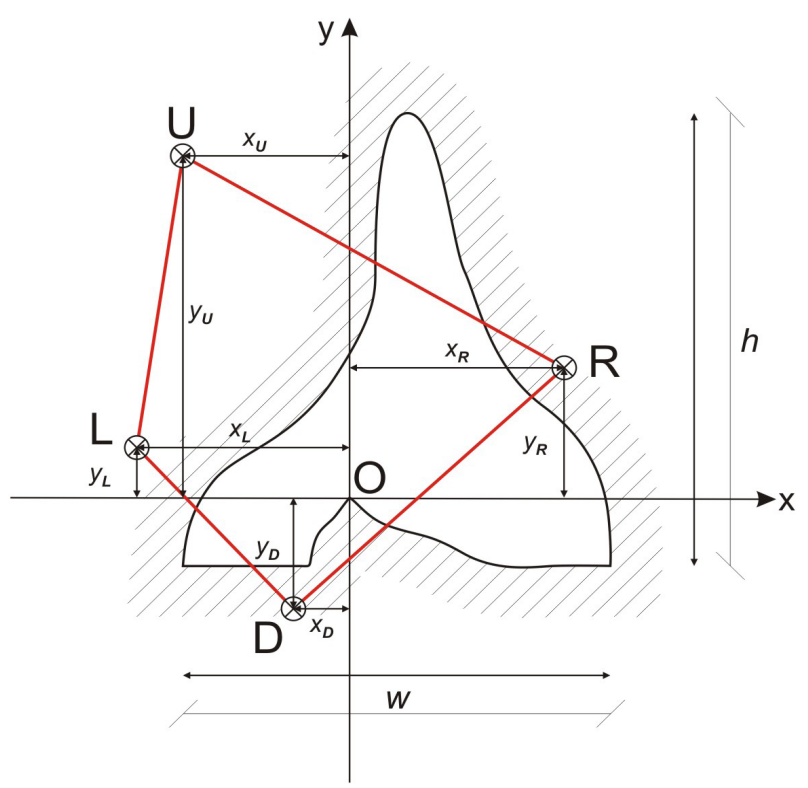

Fig. 5. Scheme of the generated and the mapped profile of the cave passages and their relation to the measured reference point $(O) ; L, R$, $\mathrm{U}$, and $\mathrm{D}$ are the corners of the virtual profile. The $\mathrm{O}$ was positioned in the middle (see Equation 1) because the profiles represent a transitional position between two stations. the calculations (see equation 2 and 4) we supposed that the relative height ( $y$-value) of the $L$ and $R$ points has a maximum at the half of the total height $(h)$. The parameters were not changed in the modeling of the SHC and the MJC. The $\xi$ random coefficient is uniformly distributed in the $[0,1]$ interval, and it was generated independently in each calculation.

$$
\begin{gathered}
x_{R}=\frac{w}{2} \\
y_{R}=y_{D}+\xi \cdot \frac{h}{2} \\
x_{L}=x_{R}-w \\
y_{L}=y_{D}+\xi \cdot \frac{h}{2} \\
x_{U}=x_{R}-\xi \cdot w \\
y_{U}=y_{D}+h \\
x_{D}=x_{R}-\xi \cdot w
\end{gathered}
$$

To calculate the $y_{D}$ value, which symbolizes the height of the station relative to the floor, the random variable $\mathrm{V}$ was applied. Due to the Central Limit Theorem, random variables like V usually have normal distribution (e.g., McPherson, 1990). The expected (mean) value of $\mathrm{V}$ was set to zero (equation 8). This means that the $\mathrm{O}$ point in the model should be closer to the floor of the cave (but not directly on it) than to the ceiling. To set the fuzziness of the measurements, it was supposed that $\mathrm{V}$ is smaller than the maximum of the absolute value of $y_{D}$ (marked as $u$ ) with 90\% probability (equation 10), if the standard deviation (D) is $20 \%$ of the height $(h)$ of the passage (equation 9 ).

$$
\begin{gathered}
\mathrm{M}(\mathrm{V})=0 \\
\mathbf{D}(\mathrm{V})=\sigma=h \cdot 0.2 \\
p(\mathrm{~V}<u)=F(u)=0.9 \\
F(u)=\frac{1}{\sigma \cdot \sqrt{2 \pi}} \cdot \int_{-\infty}^{u} e^{-\frac{t^{2}}{2 \cdot \sigma^{2}} d} \\
y_{D}=-u
\end{gathered}
$$

In equations $(10,11)$ the $F(u)$ is the cumulative distribution function and the parameter $t$ marks the infinitesimally changing discrete value in the $[-\infty, u]$ 
interval. To solve this equation for $u$, the built-in function of Excel 2003 was used (NORMINV). The negative of the results were used as $y_{D}$ in the model (12). The point $\mathrm{D}$ will be positioned at $y_{D}=0.256^{*} h$ distance from the stations according to the above equations and probability values.

It must be noted that the random parameters $(\mathrm{V}$ and $\xi)$ in the described construction method for the profiles can be modified if the cave surveying methods or the circumstances are different. It is also possible to use octagonal (like Ballesteros et al., 2011) or elliptic profiles (like Finnesand \& Curl, 2009; PardoIguzquiza et al., 2011) instead of quadrangles.

It was also found that the way the width and height data were measured also affects the results. First, the maximum measurable length (in open space) was given as the base of the modeling, and then the maximum geometric extent was also tested. The first method produced a moderate $(0.6-0.8)$ correlation between the mapped and modeled profiles, but the second approach was well acceptable with an excellent 0.83-0.97 correlation value (Table 1 ). It was found that the estimated size would be smaller if the shape of the profile is simple, and would be bigger (or nearly equal) if the shape is complicated (Fig. 6).

\section{Spatial analysis of the volumetric models}

With coordinate geometrical functions and Visual Basic scripts, a 3D shape was created in the modeling environment for each cave segment. The volumes of these objects were queried and summed. The overlapping parts were extracted from the total volume. Models of the karst massif, enclosing the cave passage model, were also created in the modeling environment as control volumes for the cave porosity calculations.

The control block enclosing the whole cave model can be defined in three ways (Fig. $7 \mathrm{a}-\mathrm{C}$ ): 1) orthogonal square prisms parallel to the coordinate axes (just like in Worthingthton's (1999) method); 2) regular block rotated to the general direction and dip of the cave; 3 ) rotated irregular prism containing the closest vicinity of the cave. Since the cave models gave estimations for the volume of the known parts of the caves, the resulting porosity proportions can be false, because the data of the model includes only the explored, but not the real extension of the existing cave passage system. Therefore, we considered more appropriate to perform a statistical analysis using small control volumes. These small volumes were regular cubes in the model space with 10-60 m edge-length (Fig. 8), and they cut the cave model at random places covering both the high and low passage-density area. A similar approach is described by Pardo-Iguzquiza et al. (2011) defining the local density of cave passages by overlapping spatial windows. The chance that a significant amount of unknown passages exists within the cubic control volume is much less than in the more extended enclosing rock volumes. A series of cubic control volume was created in the modeling environment (15-30 in every iteration) to measure the proportions of cavity in them. The location of the cubes was restricted to those spatial areas of the model where there was at least one known cave passage, which intersected the cube.

The known thickness of the limestone, which mainly incorporates the BTKS, is approximately $100 \mathrm{~m}$ (Császár, 1997). The maximum cube size was chosen accordingly for $60 \mathrm{~m}$ as the thickness of the limestone layers in most case would have exceeded the cube's body diagonal length $(103.9 \mathrm{~m})$. The minimum size was $10 \mathrm{~m}$.

For each cave, the average of the measured porosity proportions in the cubic volumes was considered as representative values of a power-curve (Fig. 9). To fit the power-curve to the values, a trust region method was used (e.g., Byrd et al., 1987). The fitted curves are sensitive to the edge-length of the control cubes. The smaller the cube was, the larger the uncertainty of the porosity test became. The maximum curvature points of the fitted porosity curves are in the uncertainty zone (where the variance of the data is large), so these points of the curves were not suitable for the porosity parameters. The bounding curves of the confidence interval around the fitted porosity curves were also calculated. To minimize the uncertainty, the estimation for the porosity-parameter $\left(a_{\mathrm{e}}\right)$ was selected at the edges of the lower bound curves. At these positions the points are close to the "elbow" of the porosity curve (=maximum curvature), but the variance is small.

\section{Estimations of unknown passages}

For each cave, it was possible to deduce the volume of the not modeled passages $\left(\mathrm{V}_{\mathrm{n}}\right)$ from three values (see Equation 13): 1) the total volume of the orthogonal prism model of the enclosing rock $\left.\left(\mathrm{V}_{\mathrm{t}}\right), 2\right)$ the cave porosity in this total volume $\left(a_{t}\right)$ and 3$)$ the estimated percentage $\left(a_{e}\right)$. Then the length of the unknown passage system $\left(\mathrm{L}_{\mathrm{n}}\right)$ was calculated with Equation (14), where $L_{m}$ is the length and $V_{m}$ is the volume of the modeled passages.

$$
\begin{gathered}
V_{n}=\frac{\left(a_{e}-a_{t}\right) \cdot V_{t}}{100} \\
L_{n}=L_{m} \cdot \frac{V_{n}}{V_{m}}
\end{gathered}
$$

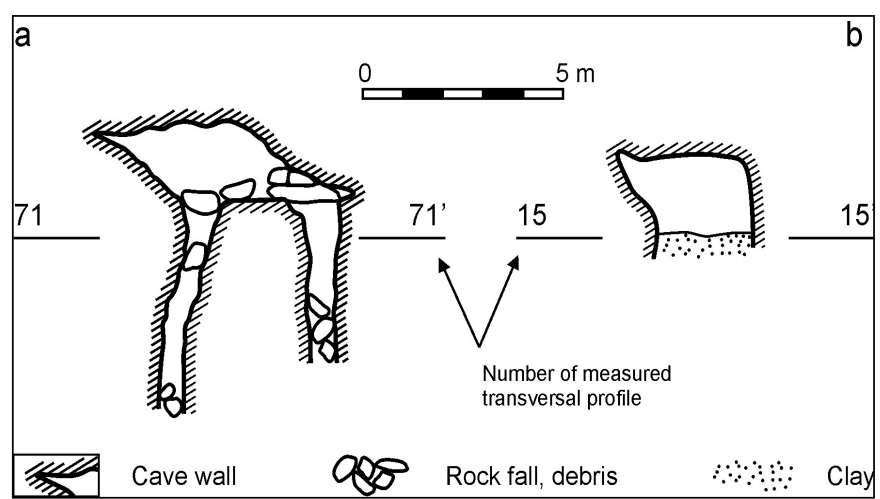

Fig. 6. Complicated and simple transverse profiles of cave passages from the SHC (a) and the MJC (b). In the case of profile-a the area of the modeled quadrangle-shaped profile was 1.7 times bigger than the mapped profile shown in the figure (average of 4 modeling session), while in the case of profile-b this multiplier was 0.6 , thus the model was smaller. 


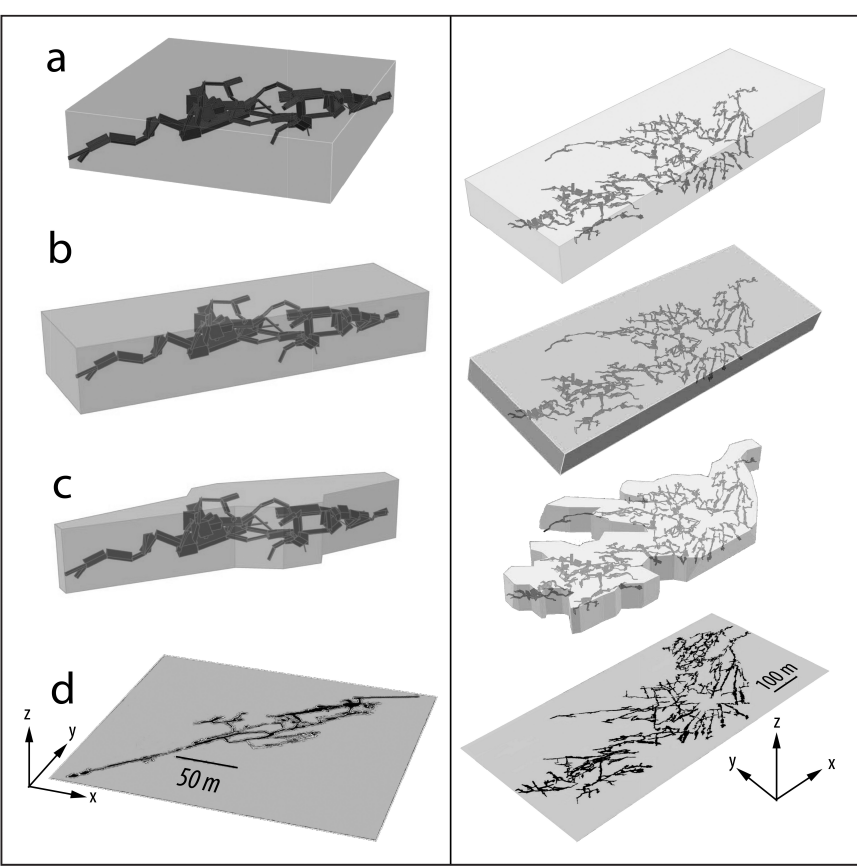

Fig. 7. Different models of the enclosing rock body of the Szemlöhegy (left) and the Pál-völgy (right) caves. The proportion of the cave porosity varies according to the shape of the enclosing rock model. a) orthogonal prisms parallel with the coordinate axes; b) rotated regular blocks; c) rotated irregular prisms; d) base maps fit into a Cartesian coordinate system (North is parallel with the y-axis).

In the calculations, the values of the minimum enclosing rock models (see row 3 of Table 2) were used for the $V_{t}$ and $a_{t}$.

Formula (13) is usable if the $a_{t}$ is less than the estimated percentage $\left(a_{e}\right)$. In the PVC and MJC the percentages of the irregular-shaped incorporating rock was used (Table 2, row 3), so the estimations for the missing/unexplored parts refer to the close vicinity of the known passage system. The total estimated volume was the sum of $V_{n}$ and $V_{m}$, and the total estimated length was the sum of $L_{n}$ and $L_{m}$ accordingly (Table 3).

In the SHC, the irregular prism-shaped enclosing rock model produced bigger percentage for the cave porosity than the estimated $\left(a_{\mathrm{e}}\right)$ value. Here the proportion of cavity in the orthogonal prism-shaped model (Table 2, row 1) was used to estimate the $V_{n}$ value. Therefore, the sums of the modeled volumes and lengths in this case refer to a slightly wider area around the modeled cave.

\section{POROSITY MODELING BASED ON OUTCROP DOCUMENTATION}

The porosity modeling was done to calculate the meso-, and macro-scale conduit porosity. The macroporosity calculated in this way was compared to the estimated macroporosity taken from the volumetric modeling of this study. Knowing the matrix porosity value taken from hydrogeological studies performed in the surroundings of PVC (Kleb et al., 1993; Juhász et al., 2007), the porosity of this karst massif (without the fracture porosity) can also be estimated.

In the abandoned quarry next to the PVC the recognizable markers were documented on the rock face. Since these markers have volume in reality, the

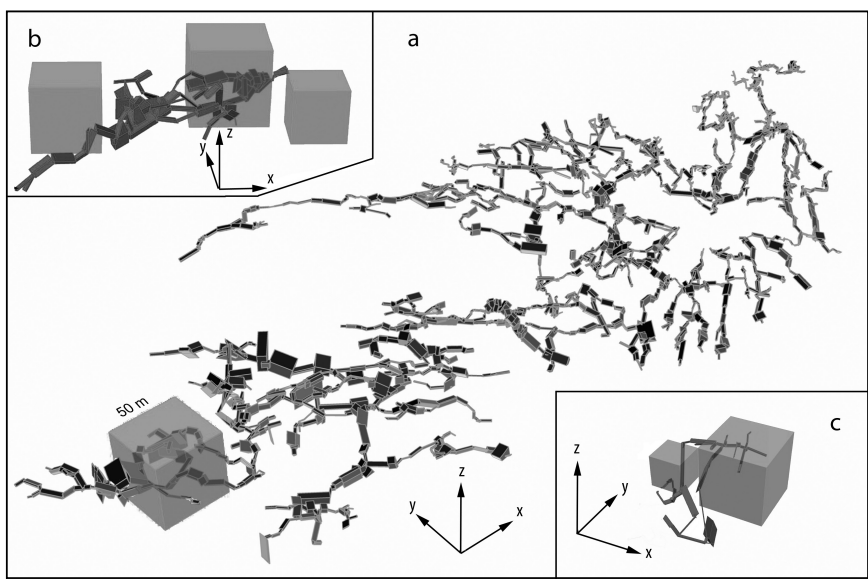

Fig. 8. Relation of the cubic models and the volumetric passage models of the BTKS caves. a) Pál-völgy Cave; b) Szemlö-hegy Cave, the edge lengths of the cubes are 30,40 , and $50 \mathrm{~m}$; c) Molnár János Cave, edge lengths are 20 and $40 \mathrm{~m}$. North is parallel with the $y$-axis.

rock face - projected on a plane - can be considered as a stereological probe that is passed through the whole rock volume (Russ \& DeHoff, 2000). After a quantitative analysis of these markers, we defined a modeling volume over the quarry, and the proportions of volumes of the different types of pores were calculated. The method of the porosity modeling is a kind of stereological approach, as it estimates the macro- and meso-scale conduit porosity from the observed features on $2 \mathrm{D}$ surface (the map of the quarry walls).

\section{Measuring the macro- and meso-scale conduit porosity}

The first step for the investigation of the macro- and meso-scale conduit porosity was taking photos of the relatively uncovered walls of the abandoned limestone quarry at the entrance of the PVC. The photos were taken with a camera placed on tripod, and the overlap of each photo was at least $40 \%$. A $2 \mathrm{~m}$ high scale bar was

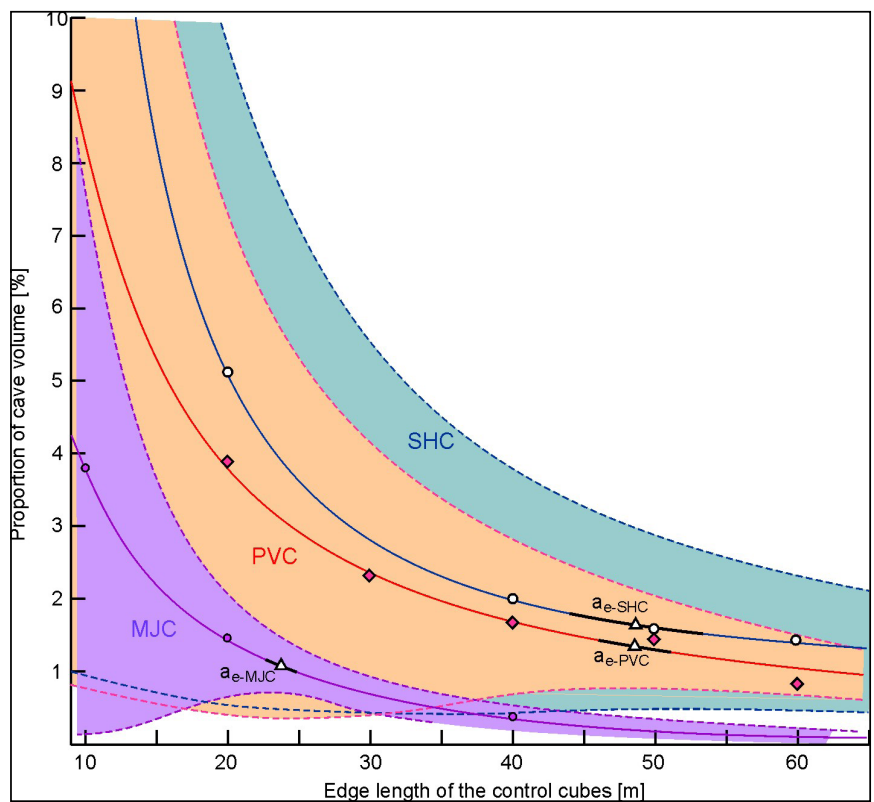

Fig. 9. The average of the porosity measurements (dots and diamonds) are representative values of fitted power-curves (continuous lines). The confidence intervals around these porosity curves were calculated from the standard deviations of the measurements. The lower bounds (dashed lines) of these intervals are approximated with the best-fitted curves. 
Table 2. Cavity proportions of the modeled caves as the function of the analyzing method of the volumetric model. PVC = Pál-völgy Cave; SHC = Szemlö-hegy Cave; MJC = Molnár János Cave .

\begin{tabular}{|l|l|c|c|c|}
\cline { 2 - 5 } \multicolumn{1}{c|}{} & $\begin{array}{l}\text { Geometric model of } \\
\text { the incorporating } \\
\text { rock }\end{array}$ & $\begin{array}{c}\text { PVC cavity } \\
\text { [\%] }\end{array}$ & $\begin{array}{c}\text { SHC cavity } \\
\text { [\%] }\end{array}$ & $\begin{array}{c}\text { MJC cavity } \\
\text { [\%] }\end{array}$ \\
\hline 1 & $\begin{array}{l}\text { Total rock volume } \\
\text { (rectangular prism) }\end{array}$ & 0.19 & 0.79 & 0.45 \\
\hline 2 & $\begin{array}{l}\text { Rotated rectangular } \\
\text { prism }\end{array}$ & 0.28 & 1.1 & - \\
\hline 3 & $\begin{array}{l}\text { Rotated irregular } \\
\text { prism }\end{array}$ & 0.54 & 2.44 & 0.63 \\
\hline 4 & Cubic model & 1.46 & 1.66 & 0.92 \\
\hline
\end{tabular}

Table 3. Volumetric parameters and the calculated sizes of the modeled caves.

\begin{tabular}{|l|c|c|c|}
\cline { 2 - 4 } \multicolumn{1}{c|}{} & PVC & SHC & MJC \\
\hline Total volume of modeled passages $\left(\mathrm{V}_{\mathrm{m}}\right)\left[\mathrm{m}^{3}\right]$ & 72,694 & 13,277 & 850 \\
\hline $\begin{array}{l}\text { Volume of the modeled incorporating rock } \\
\left(\mathrm{V}_{\mathrm{t}}\right)\left[\mathrm{m}^{3}\right]\end{array}$ & $13,380,981$ & 543,969 & 134,099 \\
\hline Estimated total volume $\left(\mathrm{V}_{\mathrm{n}}+\mathrm{V}_{\mathrm{m}}\right)\left[\mathrm{m}^{3}\right]$ & 195,539 & 27,710 & 1,234 \\
\hline Estimated total length $\left(\mathrm{L}_{\mathrm{n}}+\mathrm{L}_{\mathrm{m}}\right)[\mathrm{m}]$ & 33,833 & 2,277 & 565 \\
\hline
\end{tabular}

shot in each photo providing the base of rectification. With affine transformations and photo-joining the resulted map was relatively free of distortion (Juhász et al., 2007). On the wall-map, five vertical sections were differentiated (IA, IB, II, IIIA, IIIB) covering three sides (the fourth was open) of the quarry (Fig. 10).

The sections were divided into 24 blocks, each of which was 5-7 $\mathrm{m}$ high and $14 \mathrm{~m}$ long on average. The vertical extent of the quarry walls exceeded this measured height by $5-15 \mathrm{~m}$. Because of this and the Quaternary clayey slope-debris cover, the mapped rock surfaces were not exposed to the surface degradation effect (e.g., tension release due to denudation). For the same reason, the surface dissolution enlargement was also considered as an insignificant factor on the wallmaps. Based on geological characteristics, the blocks were classified into five categories. The categories differed from each other by the number of fissures, the frequency of dissolution traces on the separation planes and along the cracks, and the occurrence of cavities (Table 4). Most of the observed discontinuities were considered as meso-scale conduit porosity except the caves which occur only in category 5 , and are distinguished as macroporosity.

The resolution of the photos was enough to outline the fractures wider than $2 \mathrm{~cm}$, and the solution forms larger than $10 \mathrm{~cm}$. The outlined objects were analyzed with image processing software to determine the proportion of the total covered area. The result was a black-andwhite image, which showed only the pixels of the large fractures and cavities (Fig. 11). The wider the fracture or cavity was in the photo, the larger the black area was in the processed image. The number of black pixels with respect to the white ones determined the approximate proportions of the porosity (enlarged fractures, solution cavities, etc.) for each category (Table 4).

\section{The determination of pore volume}

In order to calculate the porosity model using the 2D data (photos), we established a regular grid over the area of the Pál-völgy Quarry (Fig. 10). Each cell of the grid represents one type of the determined five categories. The spatial distribution of each type was modeled according to the distributions of block types as observed on the quarry walls. The strike of the grid was calculated from the 2D vectors of the orthogonally projected map of the observed wall sections. The size of the cells in the regular isometric grid was designed to coincide with natural numbers in meters. To calculate the proper edge-length for the cubes $\left(L_{U}\right)$, each individual block was projected onto one of the axes of the grid. The result was the projected length $(L ')$ data of each block. The calculation method was based on a rounded-off value, which came from the division of the projected length $\left(L^{\prime}\right)$ by the cell unit size $\left(L_{U}\right)$. These values were then subtracted from the original divided values $\left(L^{\prime} / L_{U}\right)$, which resulted a number between 1 and -1 . Absolute difference $(d)$ is defined as:

$$
d=\left|\frac{L^{\prime}}{L_{U}}-\operatorname{round}\left(\frac{L^{\prime}}{L_{U}}\right)\right|
$$

The absolute difference $(d)$ shows the calculated error for a given cell unit size, and the rounded-off values represent the number of cell units, which can be assigned to the actual block.

We calculated the differences for all the 24 blocks for the cell unit range $1-10 \mathrm{~m}$ in sequences and estimated the mean (average) value $(\mathrm{M})$ and the distribution (D) of the differences for each of them. The seventh sequence, which had resulted the minimum M (Fig. 12), was selected as the cell unit of the grid model. The $0.173 \mathrm{~m}$ as the mean value for $d$ was considered as the error of the process, which is $2.5 \%$.

The length and width of the grid was calculated from the sum of the cell numbers assigned to blocks on the quarry walls. The number of cells assigned to the blocks of the SW wall was 23, which made the longer side of the grid to be $161 \mathrm{~m}$. The number of cells on the NW wall was 13 , which made the shorter side of the grid to be $91 \mathrm{~m}$. Since a regular 3D grid was designed, where the cells had a cubic shape, the height of the total grid was also 7 meters. This value corresponds well with the observed height of the individual blocks $(5-7 \mathrm{~m})$. The total volume of the 3D grid model was then $(161 \times 91 \times 7) 102,557 \mathrm{~m}^{3}$. The proportion of each of the five porosity categories in this volume was calculated from the distributions of these categories on the observed quarry walls (Table 5).

The total distribution estimation for the whole grid model, which consists of 299 cells (23x13), was also calculated (see the last row of Table 5). Using these values, we estimated the numbers of cells represented by each one of the five category types in the 3D grid. First, we calculated the volume of the cells represented by category types 1 to 5 , and then multiplied the result by the values determined in the visual porosity analysis (Table 6).

\section{RESULTS OF THE VOLUMETRIC MODELING}

In the volumetric modeling, 2,245 cave passages were processed. The statistical analysis has provided an estimated cave volume percentage $\left(a_{e}\right)$ for each cave 


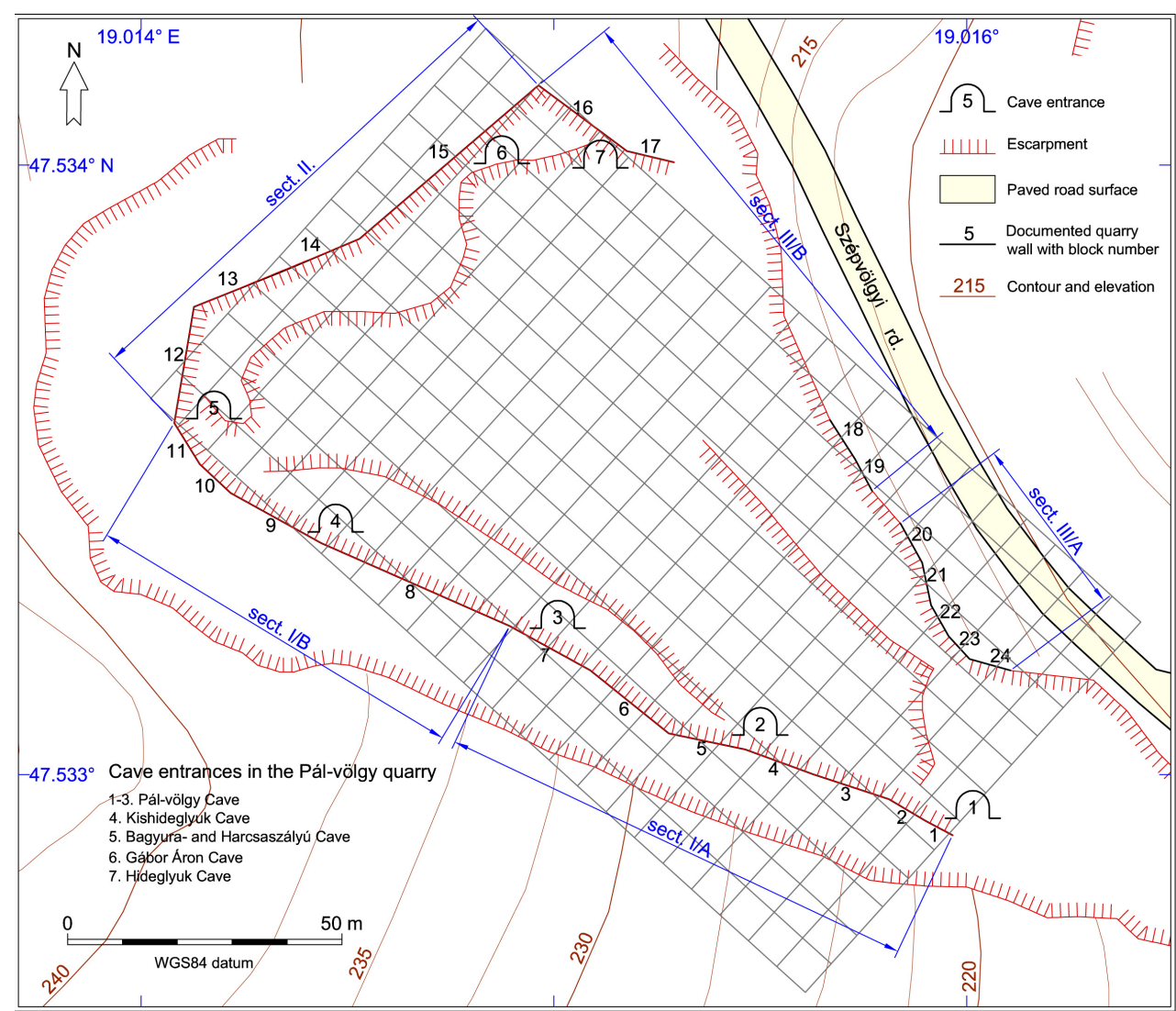

Fig. 10. Location of the measured sections, the 24 individual blocks and the calculated grid relative to the Pál-völgy Quarry. Each cell of the grid is a regular cube with $7 \mathrm{~m}$ edge-length. The direction angle of the grid's longer side is $132^{\circ}$. The listed caves are parts of the Pál-völgy Cave System (after Albert, 2010).

with the average $8-14 \%$ margin of error. The obtained results are shown in Table 2 .

\section{The Pál-völgy Cave (PVC)}

In the PVC the macroporosity parameter $\left(\mathrm{a}_{\mathrm{e}}\right)$ was $1.46 \% \pm 0.19 \%$ and the cave model filled the volume of the rock mass from 0.52 to $2.82 \%$ at this position of the fitted curve (Fig. 9). The $0.19 \%$ uncertainty was derived from the profile-modeling. Here 56 mapped transverse profiles were compared with the generated profiles, and the average error was $13 \%$. In the volumetric estimations we used only a $12.2 \mathrm{~km}$ long passage system, since at the time of the modeling the connection with the surrounding caves was not known. The modeling showed that the unexplored passages could be about twice the size $\left(122,845 \mathrm{~m}^{3}\right.$ and $20.6 \mathrm{~km}$ ) of the modeled passages over the same area. From the results of the volumetric estimations deduced from the model, the total volume of the PVC - without the other caves of the Pál-völgy Cave System - is close to $200,000 \mathrm{~m}^{3}$ and the length is around $33 \mathrm{~km}$.

\section{The Szemlö-hegy Cave (SHC)}

The modeling results of the SHC revealed a higher proportion (1.66 $\pm 0.14 \%)$ of macroporosity. This is not surprising knowing that the SHC is a relatively small cave with large caverns and a dense passage system (Leél-Össy \& Surányi, 2003). The total length of the modeled cave passages was $1,091 \mathrm{~m}$ in the SHC, which was only half of the known length. The average length of the passage segments (the edges of the 3D network) was $13.5 \mathrm{~m}$. This refers to a relatively rough geometry of the $3 \mathrm{D}$ survey network, but in this case the dense profiling improved the results. If more than one profile was assigned to the same passage, the average values of the profiles were used in the correlations. The correlation between the mapped and the modeled profiles was 0.97 , which was better than in the PVC. The average error was also less (8.4\%). Volumetric estimations in the SHC gave $2.3 \mathrm{~km}$ length, which is almost the same as the official data in the archives (Ministry of Rural Development, 2013). For this reason, significant length of unexplored passages is not expected at least within the total enclosing rock

Table 4. Criteria of the division of different rock categories based on the geological markers and the porosity values of each category.

\begin{tabular}{|c|c|c|c|c|c|c|}
\hline & Categories & 1 & 2 & 3 & 4 & 5 \\
\hline \multirow{6}{*}{ 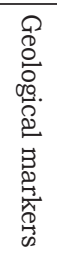 } & Stratification & $\mathrm{X}$ & $\mathrm{X}$ & $\mathrm{X}$ & $\mathrm{X}$ & $\mathrm{X}$ \\
\hline & Well developed fracture pattern & $\mathrm{X}$ & $\mathrm{X}$ & $\mathrm{X}$ & $\mathrm{X}$ & $\mathrm{X}$ \\
\hline & Solution cavities & - & $\mathrm{X}$ & $\mathrm{X}$ & $\mathrm{X}$ & $\mathrm{X}$ \\
\hline & Hemispherical niches $(0.1-0.5 \mathrm{~m})$ & - & - & $\mathrm{X}$ & $\mathrm{X}$ & $\mathrm{X}$ \\
\hline & Solution along stratification & - & - & - & $\mathrm{X}$ & $\mathrm{X}$ \\
\hline & Caves, larger cavities $(>0.5 \mathrm{~m})$ & - & - & - & - & $\mathrm{X}$ \\
\hline \multicolumn{2}{|c|}{ Porosity calculated from raster analysis } & $2.2 \%$ & $4.2 \%$ & $7.6 \%$ & $10.1 \%$ & $13.5 \%$ \\
\hline
\end{tabular}




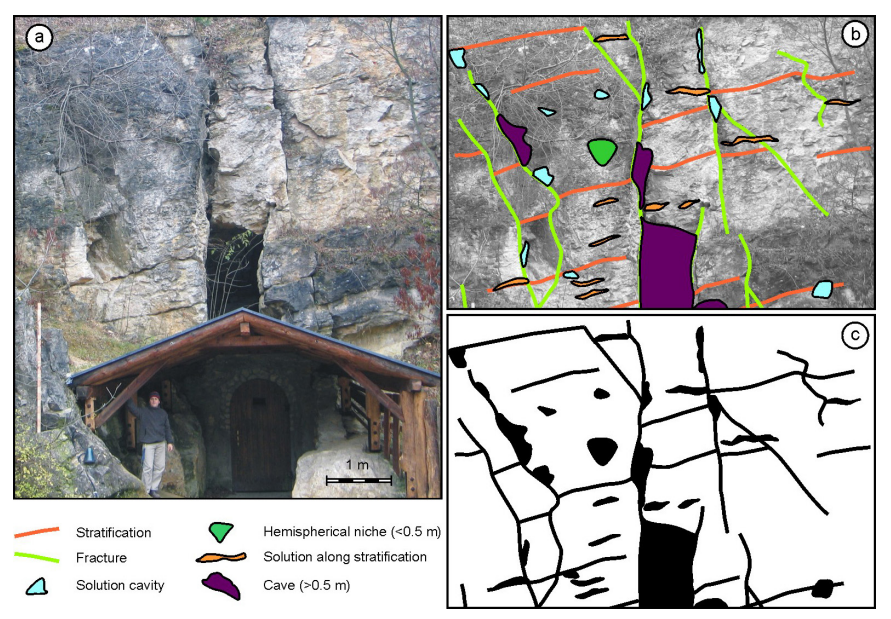

Fig. 11. Photo documentation and image analysis in the Pál-völgy Quarry (photos from Juhász et al., 2007). a) rectified photo; b) map of fractures and solution forms; c) 2 bit image of the mapped object as the base of analysis.

mass $\left(\mathrm{V}_{\mathrm{t}}\right)$ considered in the cave porosity estimations. This result is related to the fact that the SHC has a denser passage system than the PVC.

\section{Molnár János Cave (MJC)}

In the mapped part of the phreatic MJC the average width and heights of the cave passages are smaller than in the "dry caves" of the BTKS (Table 7). Because of this, the estimated proportion for the volume of the cave model was also smaller (0.92 $\pm 0.13 \%)$ than in the dry caves. This proportion was calculated with the same modeling method which was used in the other cases. Volumetric estimations in the MJC showed that instead of $389 \mathrm{~m}$ one-and-a-half times longer passages $(565 \mathrm{~m})$ can be expected over the same area.

\section{RESULTS OF THE POROSITY MODELING}

The results show that the conduit porosity of the 3D model of the Pál-völgy Quarry is 9.18\% $\pm 0.23 \%$. The distinction of the meso- and macro-scale conduitporosity is based on the difference between the category 4 and 5 . In the porosity model, category 4 and 5 were distinguished from each other, because the latter includes caves and cavities. The difference between the two percentages is $3.4 \%$, which can be assigned to category 5-type cells in the 3D grid as macro-scale conduit porosity. For the whole grid of the Pál-völgy Quarry the proportion of macroporosity is $1.23 \%$. This percentage is well comparable with the estimated $1.46 \% \pm 0.19 \%$ macroporosity value, which was determined in the volumetric modeling of the nearby PVC. The meso-scale conduit porosity is $7.95 \%$. Combining these results with previous studies about the matrix porosity in the BTKS (Kleb et al., 1993) the porosity of the study area without the fracture porosity is $14-19 \%$, max. $34 \%$.

\section{DISCUSSION}

Our method evolved during the first modeling in the PVC, where, the enclosing rock body was primarily modeled as a square prism in orthogonal
Table 5. Distribution and proportion of each type of block category observed on the three main walls of the Pál-völgy Quarry.

\begin{tabular}{|l|c|c|c|c|c|c|}
\hline \multicolumn{1}{|c|}{ Categories } & $\mathbf{1}$ & $\mathbf{2}$ & $\mathbf{3}$ & $\mathbf{4}$ & $\mathbf{5}$ & Total \\
\hline Blocks of the SW wall (pcs.) & 3 & 1 & 11 & 3 & 5 & 23 \\
\hline (\%) & 13.0 & 4.4 & 47.8 & 13.0 & 21.8 & 100 \\
\hline Blocks of the NE wall (pcs.) & 1 & 2 & 3 & 2 & 3 & 11 \\
\hline (\%) & 9.0 & 18.2 & 27.3 & 18.2 & 27.3 & 100 \\
\hline Blocks of the NW wall (pcs.) & 0 & 2 & 2 & 0 & 9 & 13 \\
\hline (\%) & 0.0 & 15.4 & 15.4 & 0.0 & 69.2 & 100 \\
\hline Total (pcs.) & 4 & 5 & 16 & 5 & 17 & 47 \\
\hline Total (\%) & 8.5 & 10.6 & 34.1 & 10.6 & 36.2 & 100 \\
\hline
\end{tabular}

Table 6. Distribution and proportion of each type of block category calculated for the 3D grid model of the Pál-völgy Quarry. The pore volumes in $\mathrm{m}^{3}$ are calculated with $2.5 \%$ uncertainty.

\begin{tabular}{|l|c|c|c|c|c|c|}
\hline Categories & $\mathbf{1}$ & $\mathbf{2}$ & $\mathbf{3}$ & $\mathbf{4}$ & $\mathbf{5}$ & Total \\
\hline Cells [pcs.] & 25 & 32 & 102 & 32 & 108 & 299 \\
\hline Cells [\%] & 8.5 & 10.6 & 34.1 & 10.6 & 36.2 & 100 \\
\hline Volume $\left[\mathrm{m}^{3}\right]$ & 8,575 & 10,976 & 34,986 & 10,976 & 37,044 & 102,557 \\
\hline Pore vol. [m $\left.{ }^{3}\right]$ & 190 & 460 & 2,700 & 1,100 & 5,000 & 9,400 \\
\hline Pore vol. [\%] & 2.2 & 4.2 & 7.6 & 10.1 & 13.5 & 9.2 \\
\hline
\end{tabular}

Table 7. Characteristics of the modeled cave segment parameters in the caves of the BTKS.

\begin{tabular}{|l|c|c|c|}
\cline { 2 - 4 } \multicolumn{1}{c|}{} & PVC & SHC & MJC \\
\hline No. of modeled segments & 2,117 & 81 & 47 \\
\hline Avg. length of segments $[\mathrm{m}]$ & 5.5 & 13.5 & 8.1 \\
\hline Avg. height of segments $[\mathrm{m}]$ & 2.75 & 7.25 & 2.37 \\
\hline Avg. width of segments $[\mathrm{m}]$ & 2.35 & 3.46 & 1.42 \\
\hline Total modeled length $\left(\mathrm{L}_{\mathrm{m}}\right)[\mathrm{m}]$ & 12,177 & 1,091 & 389 \\
\hline Total modeled volume $\left(\mathrm{V}_{\mathrm{m}}\right)\left[\mathrm{m}^{3}\right]$ & 72,694 & 13,277 & 850 \\
\hline
\end{tabular}

position containing the whole cave passage model. This preliminary result showed $0.19 \%$ macroporosity (Fig. 7a). Although this result was in accordance with a general statement that the unconfined caves only occupy $0.004-0.48 \%$ of the bedrock in which they are located (Worthington, 1999; Klimchouk, 2006), it was obvious that the porosity would increase if the volume of the enclosing rock model is decreased. Rotating and chipping of the enclosing block increased slightly, and applying the cubic control volumes increased the porosity values drastically. Still, these results were in accordance with other published data of caves with similar genesis (Weber and Bakker, 1981; Palmer, 1995; Heward et al., 2000), where the cave porosity can be $1-3 \%$.

The macro-scale conduit porosity results from the volumetric modeling were verified and confirmed by the modeling in the nearby Pál-völgy Quarry, where direct rock face measurements were carried out. The method is based on 2D measurements of interceptions of conduits by arbitrarily placed vertical planes (quarry faces) and certain extrapolation of these data through a 3D space. Although a fraction of intercepted cavities may vary greatly depending on the orientation of cross-sections relative to the cave pattern, in case of the Pál-völgy Quarry, extrapolation is favored by the fact that the quarry faces are differently oriented representing an almost closed polygon.

Comparing the macroporosity result of the two modeling methods, it was concluded that the map- 


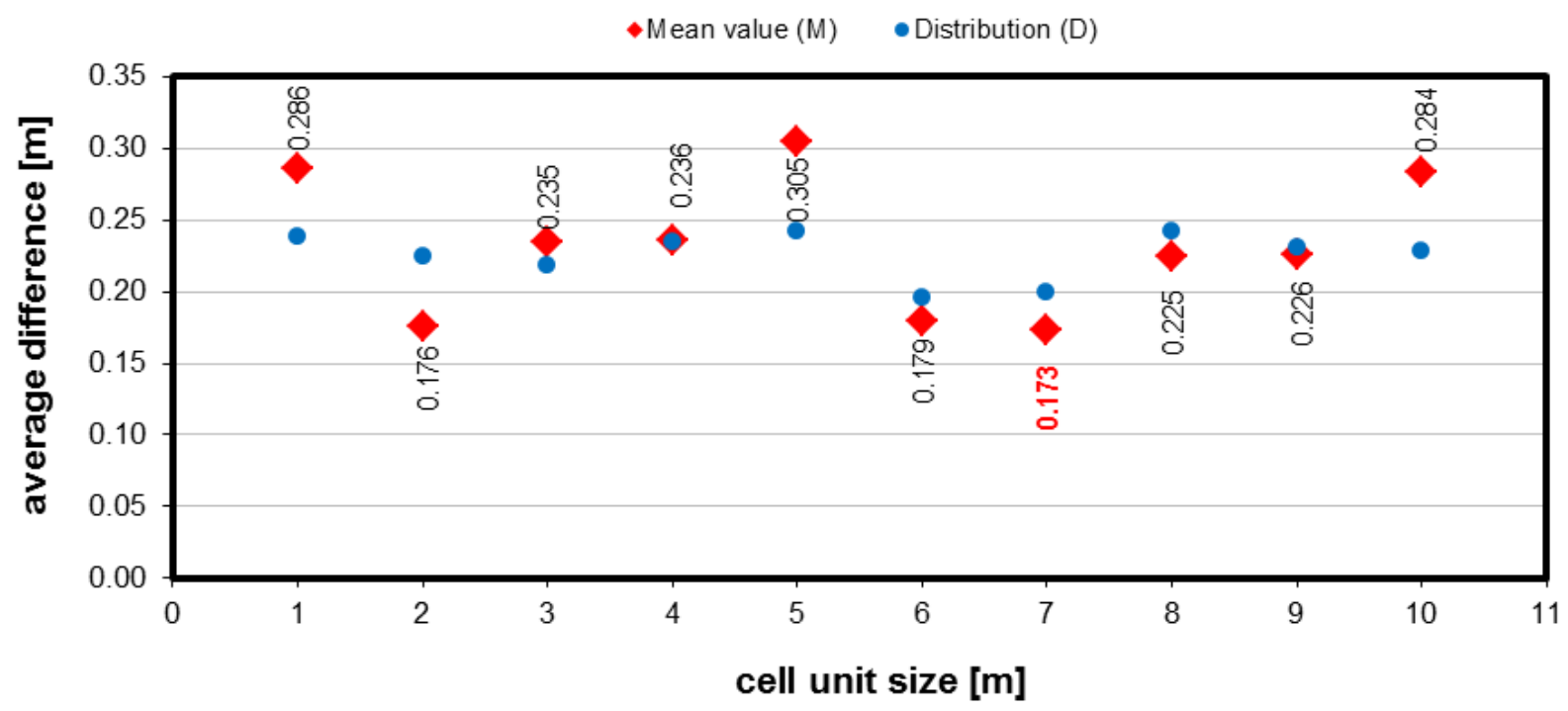

Fig. 12. Relationship between the cell unit sizes, and the $M$ and $D$ values of the average differences. The $M$ and $D$ for each cell unit size were derived from the comparison of the projected and the real length of 24 blocks.

based method of the volumetric modeling is applicable in the BTKS. The volumetric modeling produced estimation for the macro-scale conduit porosity, and if we suppose that the estimated proportions can be accepted for the whole rock volumes near the studied caves, then we could expect larger cave sizes with unexplored cave passages within the size-parameters of the karst massifs presented in this study. The MJC, and the PVC have already exceeded the here-present parameters. The application of the macroporosity data, was restricted to the karstified zone in each case, which means the close proximity of the known cave systems. Extrapolation throughout the whole region (i.e., the whole BTKS), must be handled with caution. On regional scale the regularities of the cave distribution depends on the geological settings and the hydrogeological history of the area. Thus, purely mathematical approaches may lead to false results.

The BTKS has complex geological and hydrological settings and evolutional history. However, comparison of modeling results of individual caves may be informative. In our case, the macroporosity results were quite similar in the PVC (1.46\%) and SHC (1.66\%), while in the MJC it was smaller (0.92\%). One explanation for this difference might be the speleogenetic history of the cave. The PVC and the SHC are older, already dry caves, whereas the MJC is a phreatic, actively forming cave. The composition of the host rocks might be another explanation (i.e. limestone/marl proportion). Although all three caves have a very similar position in the lithological column, a significant proportion of the modeled part of the MJC is situated in marl (based on the cave divers' experience), while in the modeled part of the PVC and the SHC the marl is subordinate (Fig. 3). The difference can also be explained with the geological and associated hydrogeological evolution of the area, in which confined conditions gradually changed to unconfined ones due to uplift and erosion. In this process, the proportion of the mixing components (cold and thermal waters) has been changed too, and in the evolving groundwater system, the proportion of karst waters increased at the expense of the basinal component as well (Eröss et al., 2011; Poros et al., 2012). All of these effects imply that during the formation of the investigated caves the different geological and hydrogeological settings might have led to different cave size.

\section{CONCLUSION}

A great amount of cave survey data is available, measured with compass and measuring tape. However, the precision of these surveys may be questionable. The volumetric modeling method is suitable for numerical estimations for the macro-scale conduit porosity using these data, and the probability of the estimation can be calculated. The porosity modeling method, combined with emerging techniques, like 3D rock face documentation based on overlapping photos (e.g., Mészáros \& Kerkovics, 2014) may become a useful tool in karst porosity modeling. The here-presented method was applied to hypogenic caves that show a typical maze pattern, and was not tested in other types of caves. In epigenic caves the speleogenesis is normally concentrated along preferential pathways, controlled by tectonic or stratigraphical factors together with the hydraulic gradient of the area (Filipponi et al., 2009). However, in the method we used for macroporosity computation, both the stratigraphic, and the tectonic control can be implemented mathematically (changing the shape parameters of the passage models). Thus, we do not exclude the possibility that our method may be applied to other types of karst.

\section{ACKNOWLEDGEMENTS}

The research of the PVC was supported by the TOTAL Corporate and the Szalai Grup SL. The modeling of the SHC and the MJC is supported by the Erdélyi Mihály Foundation. Data processing is partly supported by the Hungarian Academic Research Found (72590K). The authors thank Zsolt Kercsmár and Árpád Magyari for their contribution in the photo documentation of the Pál-völgy Quarry. We also thank all who enabled, helped 
and facilitated our project, and the reviewers for the efforts they made to improve the content of the paper.

\section{REFERENCES}

Albert G., 2010 - Volumetric modelling of cavities and pores in the Pál-völgy Cave, Budapest. Földtani Közlöny, 140: 263-280 (in Hungarian with English abstract).

Báldi T., 1986 - Mid-tertiary stratigraphy and paleographic evolution of Hungary. Akadémiai Kiadó, Budapest, $201 \mathrm{p}$.

Báldi-Beke M., 2003 - Time of the Eocene transgressions in Hungary: evaluation of the nannoplankton biostratigraphy and magnetostratigraphy. Földtani Közlöny, 133: 437-440 (in Hungarian with English abstract).

Ballesteros D., Jimenez-Sanchez M., Garcia-Sansegundo J. \& Giralt S., 2011 - Geological methods applied to speleogenetical research in vertical caves: the example of Torca Teyera shaft (Picos de Europa, northern Spain). Carbonates and Evaporites, 26: 29-40.

http://dx.doi.org/10.1007/s13146-011-0052-7

Benkovics L., Obert D., Bergerat F., Mansy J.L. \& Dubois M., 1999 - Brittle tectonics and major dextral strike-slip zone in the Buda karst (Budapest, Hungary). Geodinamica Acta, 12: 201-211.

http://dx.doi.org/10.1016/S0985-3111(00)88659-3

Byrd R.H., Schnabel R.B. \& Shultz G.A., 1987 - A trust region algorithm for nonlinearly constrained optimization. Siam Journal on Numerical Analysis, 24: 1152-1170.

Chen Y., Cai D., Fan Z., Li K. \& Ni J., 2008 - 3D geological modeling of dual porosity carbonate reservoirs: A case from the Kenkiyak pre-salt oilfield, Kazakhstan. Petroleum Exploration and Development, 35: 492-497.

Császár G., 1997 - Basic lithostratigraphic units of Hungary. Geological Institute of Hungary, Budapest, $114 \mathrm{p}$.

Curl R., 1986 - Fractal dimensions and geometries of caves. Mathematical Geology, 18: 765-783.

http://dx.doi.org/10.1007/BF00899743

Dublyansky Y.V., 2000 - Hydrothermal speleogenesis in the Hungarian Karst. In: Klimchouk A., Ford D.C., Palmer A.N. \& Dreybrodt W. (Eds.), Speleogenesis: Evolution of karst aquifers. Huntsville: National Speleological Society: 298-303.

Erőss A., Poros Zs., Mádl-Szőnyi J., Mindszenty A., Molnár F., Ronchi P. \& Csoma A.É., 2011 - Role of karstic and basinal fluids in porosity evolution in the Buda Hills, Hungary. AAPG International Conference and Exhibition 2011: Following Da Vinci's footsteps to future energy resources: Innovations from outcrops to assets, Milan, Italy, Paper 1071554.

Erőss A., Mádl-Szőnyi J. \& Csoma A.É., 2012 - Hypogenic karst development in a hydrogeological context, Buda Thermal Karst, Budapest, Hungary. In: Maloszewski P., Witczak S. \& Malina G. (Eds.), Groundwater quality sustainability: IAH selected papers on hydrogeology 17. London: CRC Press - Taylor and Francis Group: 119-133.

http://dx.doi.org/10.1201/b12715-12

Filipponi M., Jeannin P.Y. \& Tacher L., 2009 - Evidence of inception horizons in karst conduit networks. Geomorphology, 106: 86-99. http://dx.doi.org/10.1016/j.geomorph.2008.09.010

Finnesand T. \& Curl R.L., 2009 - Morphology of Tjoarvekrajgge, the longest cave of Scandinavia. In: White W.B. (Ed.), Proceedings $15^{\text {th }}$ International Congress of Speleology, Kerrville, Texas, 2: 878-883.
Fish L., 2001 - Computer modeling of cave passages. Compass \& Tape, 49: 19-24.

Fodor L., Leél-Össy Sz. \& Tari G., 1992 - En echelon fractures in a dextral shear zone - tectonic heritage for a hydrothermal cave (Budapest, Hungary). Terra Nova, 4: 165-170.

http://dx.doi.org/10.1111/j.1365-3121.1992.tb00467.x

Fodor L., Magyari Á., Fogarasi A. \& Palotás K., 1994 Tertiary tectonics and Late Paleogene sedimentation in the Buda Hills, Hungary. A new interpretation of the Buda line. Földtani Közlöny, 124: 129-305 (in Hungarian with English abstract).

Ford D.C. \& Williams P.W., 2007 - Karst hydrogeology and geomorphology. Wiley, Chichester, 576 p. http://dx.doi.org/10.1002/9781118684986

Gede M., Petters C., Nagy G., Nagy A., Mészáros J., Kovács B. \& Egri Cs., 2013 - Laser scanning survey in the Pál-völgy Cave, Budapest. In: Buchroithner M.F. (Ed.), Proceedings of the $26^{\text {th }}$ International Cartographic Conference. International Cartographic Association, Dresden: 905 p.

Haas J., 1988 - Upper Triassic carbonate platform evolution in the Transdanubian Mid-Mountains. Acta Geologica Hungarica, 34: 299-312.

Haas J., Korpás L., Török Á., Dosztály L., Góczán F., Hámor-Vidó M., Oravecz-Scheffer A. \& Tardi Filácz E., 2000 - Upper Triassic basin and slope facies in the Buda Mts. - based on study of core drilling Vérhalom tér, Budapest. Földtani Közlöny, 130: 371-421 (in Hungarian with English abstract).

Heeb B., 2008 - Paperless caving - An electronic cave surveying system. In: Proceedings IV European Speleological Congress, Vercors, 1: 130-133.

Heward A.P., Chuenbunchom S., Makel G., Marsland D. \& Spring L., 2000 - Nang Nuan oil field, B6/27, Gulf of Thailand: karst reservoirs of meteoric or deep-burial origin? Petroleum Geoscience, 6: 15-27.

http://dx.doi.org/10.1144/petgeo.6.1.15

Horváth J., 1965 - A Szemlöhegyi-barlang 1961-62. évi felmérése [Survey of the Szemlöhegy Cave, 1961-62]. Karszt és Barlang, 9: 21-30.

Jakopin P., 1981 - Macrostereological evaluation of cave space. In: Kalisnik M. (Ed.), Stereologica Iugoslavia, contemporary stereology. Proceedings of the $3^{\text {rd }}$ European Symposium for Stereology, Ljubljana, 3: 621-628.

Jakucs L., 1948 - A hévforrásos barlangkeletkezés [Geology of cavern formation by thermal spring activity]. Hidrológiai Közlöny, 28: 1-6.

Jeannin P.-Y., Groves C. \& Häuselmann P., 2007 Speleological investigations. In: Goldscheider N. \& Drew D. (Eds.), Methods in karst hydrogeology. London: Taylor \& Francis: 25-44.

Juhász E., Albert G., Budai T., Kercsmár Z., Magyari Á. \& Nádor A., 2007 - Hydrothermal alteration and karstification of Triassic and Eocene carbonates, Buda Mountains, Central Hungary. TOTAL Corporate, Buda Project.

Kalinovits S., 1984 - Molnár János-barlang [Map of the Molnár János Cave]. Magyar Karszt és Barlangkutató Társulat, scale 1:250.

Kalinovits S., 2006 - The exploration of new passages of Molnár János Cave. Karszt és Barlang, 58: 3-10.

Kárpát J., 1983 - A Pál-völgyi-barlang [Map of the Pálvölgy Cave]. Magyar Karszt és Barlangkutató Társulat, scale 1:250.

Kázmér, M., 1985 - Microfacies pattern of the Upper Eocene limestones at Budapest, Hungary. Annales Universitatis Scientiarium Budapestinensis de Rolando Eötvös Nominatae Sectio Geologica, 25: 139-152. 
Kele S., Scheuer Gy., Demény A., Shen C-C. \& Chiang H.-W., 2009 - U-series dating and isotope geochemical study of the Gellért Hill (Budapest) travertine. Central European Geology, 52: 199-224.

Kele S., Scheuer Gy., Demény A., Shen C-C. \& Chiang H.-W., 2011 - Uranium-series dating and geochemical analysis of the travertines located on the Rózsadomb (Budapest). Földtani Közlöny, 141: 293-312 (in Hungarian with English abstract).

Kincaid T.R., 2000 - Mapping and modeling the morphology of underwater caves in the Taurus Mountains and Antalya Travertine Plateau, Southern Turkey. Underwater Science and Technology Meeting, Middle East Technical University, Ankara Turkey.

Király L., 1975 - Rapport sur l'état actuel des connaissances dans le domaines des caractères physiques des roches karstiques. In: Burger A. \& Dubertret L. (Eds.), Hydrogeology of karstic terrains. International Union of Geological Sciences: 53-67.

Kleb B., Benkovics L., Dudko A., Gálos M., Juhász E., Kertész P., Korpás L., Marek I., Nádor A. \& Török Á., 1993 - Complex geological investigations and drillings in the surroundings of Rózsadomb. Geological, petrophysical, tectonic and palaeokarst analysis and evaluation. Department of Engineering Geology, Budapest Technical University, Phare 134/2. project report, 341.

Klimchouk A.B., 2003 - Unconfined versus confined speleogenetic settings: variations of solution porosity. Journal of Speleogenesis and Evolution of Karst Aquifers, 1 (2): 7 p.

Klimchouk A.B., 2004 - Morphometry of caves. In: Gunn J. (Ed.), Encyclopedia of cave and karst science, New York: Fitzroy Dearborn: 526-528.

Klimchouk A.B., 2006 - Unconfined versus confined speleogenetic settings: variations of solution porosity. International Journal of Speleology, 35: 19-24. http://dx.doi.org/10.5038/1827-806X.35.1.3

Klimchouk A.B., 2007 - Hypogene speleogenesis: Hydrogeological and morphogenetic perspective. National Cave and Karst Research Institute, Carlsbad, $106 \mathrm{p}$.

Klimchouk A.B. \& Ford D., 2000 - Types of karst and evolution of hydrogeologic settings. In: Klimchouk A.B., Ford D., Palmer A. \& Dreybrodt W. (Eds.), Speleogenesis: Evolution of karst aquifers. Huntsville: National Speleological Society: 45-53.

Laverty M., 1987 - Fractals in karst. Earth Surface Processes and Landforms, 12: 475-480.

http://dx.doi.org/10.1002/esp.3290120505

Leél-Össy Sz., Szanyi G. \& Surányi G., 2011 - Minerals and speleothems of the Jozsef-hegy Cave (Budapest, Hungary). International Journal of Speleology, 40: 191-203.

http://dx.doi.org/10.5038/1827-806X.40.2.11

Leél-Őssy Sz. \& Surányi G., 2003 - The peculiar hydrothermal caves in Budapest (Hungary). Acta Geologica Hungarica, 46: 407-436.

http://dx.doi.org/10.1556/AGeol.46.2003.4.5

Manda A.K. \& Gross M.R., 2008 - Identifying and characterizing solution conduits in karst aquifers through geospatial (GIS) analysis of porosity from borehole imagery: An example from the Biscayne aquifer, South Florida (USA). Advances in Water Resources, 29: 383396.

http://dx.doi.org/10.1016/j.advwatres.2005.05.013
McPherson G., 1990 - Statistics in scientific investigation: Its basis, application and interpretation. SpringerVerlag, $692 \mathrm{p}$. http://dx.doi.org/10.1007/978-1-4757-4290-9

Mészáros J. \& Kerkovics K., 2014 - Possible use of small $U A V$ to create high resolution $3 D$ model of vertical rock faces. Geophysical Research Abstracts, 16: Paper 16085.

Ministry of Rural Development, Hungary, 2013 - National Cave Register. http://www.termeszetvedelem.hu [accessed: July 28, 2013].

Müller P. \& Magyar I., 2008 - The Pannonian deposits of the Buda Mountains. Földtani Közlöny, 138: 345-356 (in Hungarian with English abstract).

Nagymarosy A. \& Báldi-Beke M., 1988 - The position of the Paleogene Formations of Hungary in the standard Nannoplankton zonation. Annales Universitatis Scientiarum Budapestinensis de Rolando Eötvös Nominatae, Sectio Geologica, 28: 3-25.

Nagymarosy A., 2001 - Hungarian Palaeogene Basin. In: Haas J. (Ed.), Geology of Hungary. Budapest: Eötvös University Press: 133-135.

OSM - OpenStreetMap. http://www.openstreetmap.org/ OpenStreetMap Foundation [accessed: July 28, 2013].

Pachos A., 2008 - An empirical study of cave passage dimensions using augmented radial and longitudinal survey data. [MSc Thesis]: University of Akron, USA.

Palmer A.N., 1995 - Wind Cave: an ancient world beneath the hills. Black Hills Parks and Forests Association, Hot Springs, S.D., 64 p.

Palmer A.N., 1999 - Perspectives in karst hydrogeology and cavern genesis. In: Palmer A.N., Palmer M.V. \& Sasowsky I.D. (Eds.), Karst modelling. Charlottesville, Virginia: Karst Waters Institute, Special Publication 5: 17-30.

Palmer A.N., 2007 - Cave geology. Cave Books, Dayton, 454 p.

Pardo-Iguzquiza E., Duran-Valsero J.J. \& RodriguezGaliano V., 2011 - Morphometric analysis of three-dimensional networks of karst conduits. Geomorphology, 132: 17-28. http://dx.doi.org/10.1016/j.geomorph.2011.04.030

Piccini L., 2011 - Recent developments on morphometric analysis of karst caves. Acta Carsologica, 40: 43-52.

Poros Zs., Mindszenty A., Molnár F., Pironon J., Győri O., Ronchi P. \& Szekeres Z., 2012 - Imprints of hydrocarbon-bearing basinal fluids on a karst system: mineralogical and fluid inclusion studies from the Buda Hills, Hungary. International Journal of Earth Sciences, 101: 429-452. http://dx.doi.org/10.1007/s00531-011-0677-8

Russ J.C. \& DeHoff R.T., 2000 - Practical stereology. New York: Plenum Press: 307 p. http://dx.doi.org/10.1007/978-1-4615-1233-2

Scheuer Gy. \& Schweitzer F., 1988 - A Gerecse és a Budaihegység édesvizi mészkőösszletei (The freshwater limestone beds of the Gerecse and Buda hills). Földrajzi Tanulmányok 20, Akadémiai Kiadó, Budapest, 129 p (in Hungarian).

Szanyi Gy., Surányi G. \& Leél-Őssy Sz., 2012 - Cave development and Quaternary uplift history in the Central Pannonian Basin derived from speleothem ages. Quaternary Geochronology, 14: 18-25.

http://dx.doi.org/10.1016/j.quageo.2012.09.001

Szunyogh G., 1989 - Theoretical investigation of the development of spheroidal niches of thermal water origin, second approximation. In: Kósa A. (Ed.), Proceedings of the $10^{\text {th }}$ International Congress of Speleology, Budapest, 3: 766-768. 
Takács-Bolner K., 2011 - The Rózsadomb caves and their contribution to the development of Hungarian speleology. 100 Years of the organized Hungarian Speleology, Budapest, 2011.

UNESCO - Caves of the Buda Thermal Karst System. http://whc.unesco.org/en/tentativelists/282/ UNESCO [accessed: July 12, 2013].

Verbovšek T., 2007 - Fractal analysis of the distribution of cave lengths in Slovenia. Acta Carsologica, 36: 369-377.

Virág M., Kálmánfi-Ast H. \& Mindszenty A., 2013 Barlangszintek, barlangi kiválások és travertinók térbeli jellemzése (Spatial characterization of cave levels, cave minerals and travertines). In: Mindszenty A. (Ed.), Budapest: földtani értékek és az ember (Budapest: geoheritage and humans - urban geological studies), ELTE Eötvös Kiadó, Budapest: 259-263 (in Hungarian).

Weber K.J. \& Bakker M., 1981 - Fracture and vuggy porosity. Society of Petroleum Engineers Annual Technical Conference, San Antonio, Texas.
Wein Gy., 1977 - A Budai-hegység tektonikája (Tectonics of the Buda Hills). Special Publication of the Geological Institute of Hungary, Budapest, 76 p.

Worthington S.R.H., 1999 - A comprehensive strategy for understanding flow in carbonate aquifers. In: Palmer A.N., Palmer M.V. \& Sasowsky I.D. (Eds.), Karst modelling. Charlottesville, Virginia, Karst Waters Institute, Special Publication 5: 30-37.

Worthington S.R.H., Ford D.C. \& Beddows P.A., 2000 Porosity and permeability enhancement in unconfined carbonate aquifers as a result of solution. In: Klimchouk A., Ford D., Palmer A., Dreybrodt W. (Eds.), Evolution of karst aquifers. Huntsville: National Speleological Society: 463-472.

Zentay P., 2005 - The exploration of the Pál-völgy Cave since 1980. Genesis and formations of hydrothermal caves. Proceedings of the International Conference of the occasion of the $100^{\text {th }}$ anniversary of the discovery of Pál-völgy Cave, Budapest, 134-139. 